\title{
BEHAVIORAL INTERACTIONS BETWEEN LIRIS NIGRA VAN DER LINDEN (HYMENOPTERA: SPHECIDAE) AND GRYLLULUS DOMESTICUS L. (ORTHOPTERA: GRYLLIDAE).
}

\author{
By A. L. Steiner*
}

\section{Abstract}

This study surveys and attempts to interpret the different behavioral interactions between the solitary wasp Liris nigra V.d.L. and crickets of the species Gryllulus domesticus L. in different hunting situations. Significant variations are recorded, some of which are predictable, others not. Wasp-cricket interactions and responses become more frequent, vigorous and complete from onset to peak of the hunting phase. Discussion is concerned mainly with releasing conditions, with characteristics and possible meaning of the interactions and responses. The problem is placed in the context of general defense, alarm reactions, predator-prey interactions and possible corresponding behavioral adaptations.

\section{INTRODUCTION}

Liris nigra V.d.L., a palearctic sphecoid hunting wasp, paralyzes only crickets, of various species, both adults and immatures (Berland, 1925; Bernard, 1935; Ferton, I901b, 1905, I911, 1914; Kohl, I884). In southern France, the nesting period of this wasp generally extends from May to July and August, the peak being in late June and early July. The wasps emerge in autumn and overwinter as adults in pre-existent burrows, galleries and other cavities in the soil. Non-nesting activity does not completely stop in winter, but it increases rapidly in spring. It consists mainly of basking in the sun, body grooming, feeding and locomotor activities; the latter involving "visits" to pre-existent burrows, in which the wasp passes the night.

*Present address: Department of Zoology, University of Alberta, Edmonton, Alberta, Canada.

Research has been sponsored by the "Centre National de la Recherche Scientifique" - Paris. It has been conducted from 1954 to 1964, at the Universities of Paris (Laboratoire d'Evolution des Etres Organisés and Station Biologique des Eyzies - Direct. Prof. P.-P. Grassé) and Montpellier, France (Laboratoire de Zoologie et Biologie Animale-Direct. Prof. O. Tuzet; Laboratoire de Psychophysiologie et Comportement Animal - Direct. A. L. Steiner).

Manuscript received by the editor July 19, 1968 
Occasionally prey-paralyzing and digging behavior occur outside the nesting period.

During the nesting season, the daily rhythm involves, in addition to the preceding activities, nesting activities organized into nesting cycle(s). Responses of crickets to wasps are basically associated with this nesting cycle and depend in part on certain properties of it. Although considerable variation in nesting cycles has been recorded (Steiner, I962), the following succession of activities has been observed most frequently and is considered as typical and predictable. The variability is greatly reduced if unusual interference with activities of the nesting wasps is minimized or eliminated altogether.

A simplified outline of the typical nesting cycle of Liris nigra is presented below.

I. Nesting consists of burrow-digging, but more frequently the wasp uses pre-existent burrows and galleries in the soil, if available (Berland, 1925, 1929; Ferton, I901b ; Grandi, I954; Steiner, 1957a, I957b, I962).

2. Prey capture involves prey-paralyzing (for detailed study see Steiner, I958a, I958b, I962, I963a, I963b).

3. Malaxation of cricket involves the wasp compressing (or crushing) between the mandibles the base(s) of fore $\operatorname{leg}(\mathrm{s})$ (Steiner, 1957c, I962).

4. Prey-carriage. The prey is dragged over the soil; the wasp walks head first, grasping the antennae of the prey between the mandibles (Ferton, I90Ib; Steiner, 1957c, 1962).

5. Second malaxation, inside the nest (in the terminal cell). See above, point 3, and Steiner, I957c, I962.

6. Egg laying. The wasp glues the egg across the ventral part of the thorax of the cricket, between the fore and middle legs (Berland, I925; Ferton, I90Ib; Steiner, I962).

7. Nest closure. The wasp generally uses soil particles, small pebbles, etc. if pre-existent burrows in hard soil are involved; alternatively, if the burrow was dug by the wasp or found in soft soil, the wasp scrapes in soil from the periphery of the entrance (Fabre, I 856a; Ferton, I90Ib; Berland, I925, I929; Steiner, I957a, I957b, 1962).

The prey-capturing phase of the typical nesting cycle is the main concern of this paper.

CONDITIONS OF OBSERVATION AND EXPERIMENTATION

Liris nigra has been raised in captivity for twelve years (between I952 and 1964) (Steiner, 1965). 
In order to elininate possible additional variables, only one species of cricket, Gryllulus domesticus L. has been used. Liris nigra generally succeeds in paralyzing immatures only. Adults, although attacked, are apparently too large for this species of wasp.

This paper represents observations made during detailed study of paralyzing behavior of the wasp. Several aspects of the wasp-cricket interaction are developed more fully than in previous publications (Steiner, 1962).

\section{COMMON BEHAVIORAL RESPONSES IN USUAL HUNTING CONDITIONS:} MAIN CHARACTERISTICS

It is convenient to subdivide the hunting phase of the nesting cycle into two periods, termed "early" (Plate 21) and "full" (Plates 22 and 23) hunting phases. No clear cut line separates these periods. The most typical characteristics of each are given in Table $\mathrm{I}$.

The hunting phase provides an overall graded scale of increasing intensities and degrees of completeness from onset to completion. This hunting phase is used here as a framework for studying the responses of the prey and especially the intensity-dependent aspects of these responses.

Except for the hunting phase of the typical nesting cycle, crickets and Liris typically seem to ignore each other. However, a wasp occasionally pounces on a cricket at other times and even paralyzes it. This can be observed at early stages of the daily cycle of activities before the wasp is engaged in the nesting cycle and rarely even outside the nesting season itself. Malaxation generally follows this and then the cricket is abandoned.

Interactions of wasps and crickets consistently change throughout the hunting phase like many other parameters described in Table I.

\section{INTERACTIONS AND RESPONSES TYPICAL OF EARLY HUNTING PHASE}

(Represented on Plate 2i)

These interactions become more frequent, vigorous and complete from onset to peak of the hunting phase. Increase in vigor of the interaction (parameters 5 of Table $\mathrm{I}$ ) is indicated by an increase in the number of arrows on the path followed by the wasp. The line representing this path is more direct and less frequently interrupted from a to $\mathrm{f}$. It indicates that the displacements of the wasp become more direct and selective (parameter 3 of Table I) and less frequently interrupted by non-hunting activities or rest (parameter 4 of Table I).

For simplification, crickets are supposed to be motionless and at rest before the interaction (Figure 0 , Plate 2I). 
Table 1. Typical changes from onset to completion of hunting phase. ${ }^{1}$

\begin{tabular}{|c|c|c|}
\hline \multirow[b]{2}{*}{ Different parameters compared } & \multicolumn{2}{|c|}{ Hunting phase } \\
\hline & $\begin{array}{cc}\text { Onset } & \text { to } \\
\text { "early" } & \text { to }\end{array}$ & $\begin{array}{l}\text { Completion' } \\
\text { "full" }\end{array}$ \\
\hline $\begin{array}{l}\text { 1. Responsiveness of wasps to } \\
\text { crickets. }\end{array}$ & $\begin{array}{l}\text { low (increas- } \\
\text { ing gradually) }\end{array}$ & high \\
\hline $\begin{array}{l}\text { 2. Duration and importance } \\
\text { of preliminaries of attack. }\end{array}$ & $\begin{array}{l}\operatorname{maximum} \\
\text { ("loitering") }\end{array}$ & minimum \\
\hline $\begin{array}{l}\text { 3. Directiveness and selec- } \\
\text { tivity of displacements, } \\
\text { movements of wasps, be- } \\
\text { fore contacts with crickets. }\end{array}$ & poor & $\operatorname{good}^{3}$ \\
\hline $\begin{array}{l}\text { 4. Interruption of hunting } \\
\text { by non-hunting activities } \\
\text { (feeding, grooming, etc.) } \\
\text { or by periods of inactivity. }\end{array}$ & $\begin{array}{l}\text { frequent } \\
\text { important }\end{array}$ & $\begin{array}{l}\text { limited or } \\
\text { absent } \\
\text { very short }\end{array}$ \\
\hline $\begin{array}{l}\text { 5. Quality of attacks and at- } \\
\text { tempts of manipulation of } \\
\text { the cricket. }\end{array}$ & $\begin{array}{l}\text { weak, } \\
\text { "sluggish", } \\
\text { often aborted }\end{array}$ & $\begin{array}{l}\text { vigorous, } \\
\text { sustained, } \\
\text { complete }\end{array}$ \\
\hline $\begin{array}{l}\text { 6. Proportion of investiga- } \\
\text { tion of crickets not fol- } \\
\text { lowed by attack. }\end{array}$ & high & low \\
\hline $\begin{array}{l}\text { 7. Proportion of investiga- } \\
\text { tions and attacks not fol- } \\
\text { lowed by pursuit and } \\
\text { stinging. }\end{array}$ & high & low \\
\hline $\begin{array}{l}\text { 8. Proportion of attacks and } \\
\text { stinging not followed by } \\
\text { other prey handling activi- } \\
\text { ties. }\end{array}$ & very high & very low \\
\hline $\begin{array}{l}\text { 9. Degree of completion of } \\
\text { prey-stinging pattern. }\end{array}$ & $\begin{array}{l}\text { low (if any } \\
\text { prey-stinging) }\end{array}$ & $\begin{array}{l}\text { high } \\
\text { (generally } \\
\text { maximum) }\end{array}$ \\
\hline $\begin{array}{l}\text { 10. Level of antagonistic in- } \\
\text { teractions between wasps. }\end{array}$ & low & high \\
\hline
\end{tabular}

${ }^{1}$ Table 1 is concerned with general trends only.

${ }^{2}$ Passage from early to full hunting phase is not necessarily gradual. Changes can be sudden or show fluctuations, often cyclical (Steiner, 1962).

${ }^{3}$ The wasp might also be guided toward favorable areas by memory of past hunting trips (Steiner, 1962).

${ }^{4}$ The complete pattern of prey stinging typically involves four stings (Steiner, 1962).

${ }^{5}$ Incomplete paralysis results from incomplete set of stings and the cricket is generally abandoned immediately (Steiner, 1962).

${ }^{6}$ This level is extremely low in non-nesting interactions, even in feeding; however wasps in their overnight burrows may threaten or drive away intruding wasps (or other insects). 


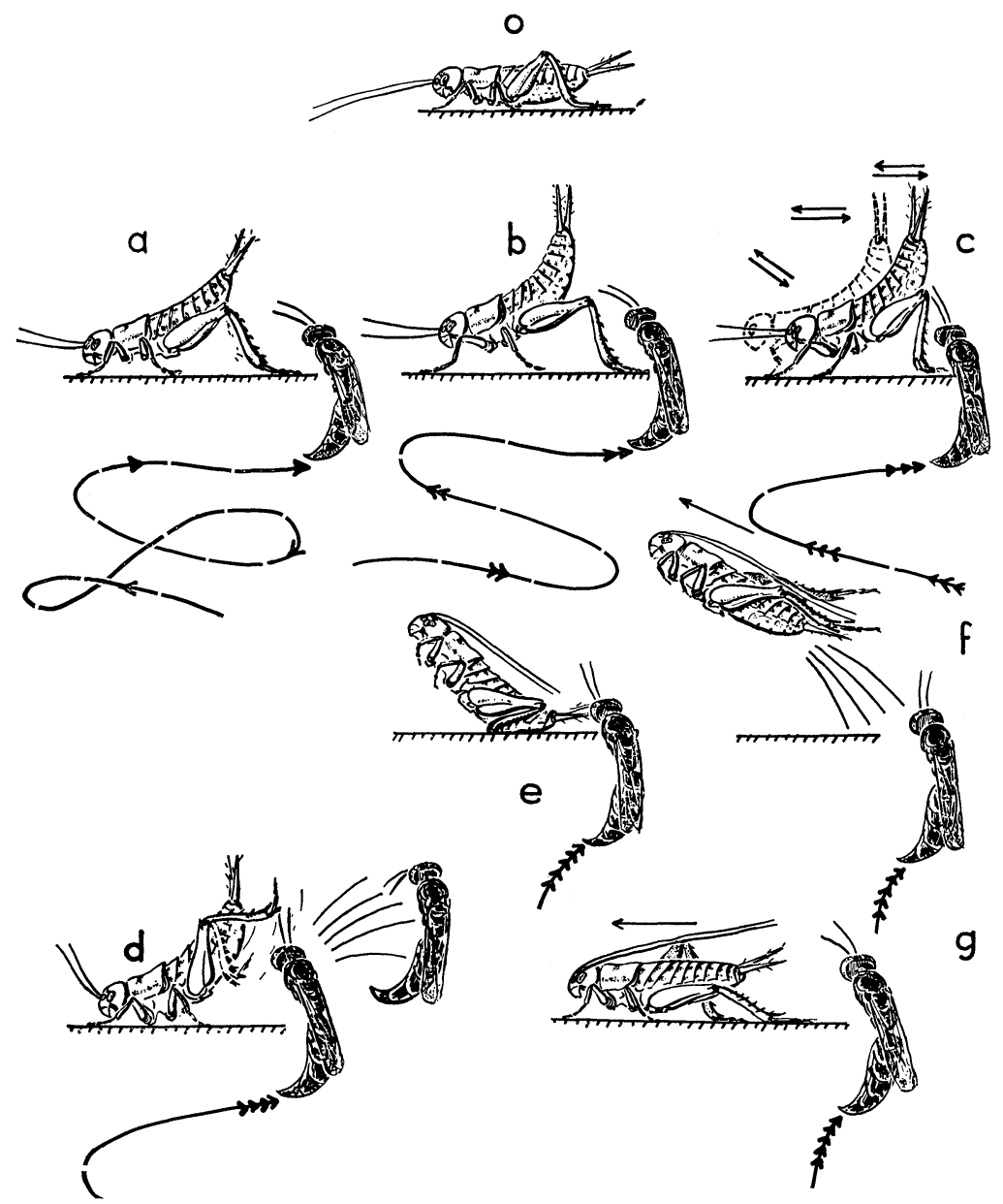

Wasp-prey interaccions and responses typical of early hunting phase. Fig. 0-Typical resting posture. Fig. a-Raising abdomen. Fig. bTilted posture. Fig. c-Body swaying, in tilted posture. Fig. d-Kicking with jumping (hind) legs. Figs. e, f-Jumping away. Fig. $g$-Running away. Solid lines indicate movements and displacements of prey. Interrupted lines indicate the path followed by the wasp. Increasing vigor of attacks is represented by increasing number of arrows from a to f. Explanations in text. 
Description of responses represented by figures a to $c$.

Fig. a. Raising abdomen. This response is typical of very early stages of the hunting phase, when the wasp makes only weak, slow abortive attempts to investigate or attack the cricket. The cricket typically comes back quickly to the original "resting posture" 0 , or alternatively gives way to the wasp by a slight side movement of withdrawal.

Fig. b. Raising abdomen and body in a tilted posture ("on tiptoes"). This can be considered a more accentuated, complete version of the preceding response, involving apparently no new element. Raising of both the abdomen and the whole body above ground level is accentuated, in response to attacks of the wasps generally more vigorous than in the preceding instance.

Fig. c. Body swaying, in tilted posture, abdomen raised. New elements appear in this response, e.g., back and forth, side, or combined swaying movements performed in a jerky manner; extremities of legs generally are not lifted.

This response is frequently associated with more intense and sustained, sometimes repeated attempts of investigation by the wasp. It is, like the preceding ones, typical of abortive attacks.

At this stage of the intensity scale, threshold for escape seems nearly reached, but subsequent escape is the exception.

Discussion of responses represented on figures a to $c$.

Interactions shown in figures a to $c$ appear to involve increasing levels of recruitment and mobilization of responses from the previously resting cricket. Various movements of increasing amplitudes are apparently triggered. Displacements, which occur at a further stage (see figures $f, g$ ), probably involve higher levels of recruitment.

If this interpretation is correct, swaying movements, (see fig. c), might represent the stage of transition from movements of the previously resting cricket to displacements and escape.

The response represented on figure $c$ might express oscillations in competitive influences associated respectively with rest and escape, none of them being strong enough to override the other completely. If so this could lead to interpretations in terms of conflict or ambiguous situations, intention movements, ambivalent behavior, alternation, compromise behavior, etc. (discussion of these terms and literature references are available, for instance, in Hinde, 1966; Tinbergen, I952). Alternatively, this response might be associated with non-detected special features of the interaction, which are not necessarily intensity-dependent. 
Description of responses represented in figures $d, e, f, g$.

Fig. d. Kicking with hind (jumping) legs, in an abdomen upright posture. This has been observed less frequently than any other response shown on Plate $2 \mathrm{I}$; the wasp might or might not be kicked away at various distances from the cricket. Probability of subsequent attack is low and this is in sharp contrast with same response occurring in full hunting phase (see Pl. 22, fig. i). Intense grooming or other non-hunting activities are frequently performed by the "kicked wasp".

No graded series comparable to the one represented on figures $a, b, c$, has been recorded for response shown on figure $d$, the occurrence of which is rather unpredictable. Therefore its position on the scale of intensities is more arbitrary and difficult to evaluate. Other intensity dependent parameters of the hunting phase have been used, especially the vigor of the attempts of the wasp to investigate the cricket. Apparent level of recruitment of responses of the cricket and relative violence of them appear to be intermediate between responses represented on figures $\mathrm{a}, \mathrm{b}$, $\mathrm{c}$, which are less violent, and escape responses shown on figures $f, g$, which are more complete.

Fig. e, f. Jumping away; Fig. g. Running away (escape reactions). These probably represent more complete mobilization of the cricket and are characteristically associated with more vigorous and sustained attacks of the wasps involving sudden "pouncing". They have therefore been placed at the top of the intensity scale. Roeder gives a very precise analysis of "evasive reactions" in cockroaches.

Probability of subsequent pursuit is, however, still relatively low, which is in contrast with full hunting phase. Vigor of the attacks does not appear to be consistently different for running response versus jumping response, although suddenness of attack might favor the latter slightly.

INTERACTIONS AND RESPONSES TYPICAL OF FULL HUNTING PHASE

(represented on Plate 22).

These almost invariably involve displacement and escape of the cricket (except response shown on fig. i). They are consistently associated with vigcrous, sustained attacks and attempts at catching the crickets. Wasps seem to have reached an optimal level of responsiveness to crickets and intensity of hunting reactions. Therefore these responses lack, in general, any predictable "gradation". Interactions are represented on Plate 22 in function of possible orders of succession, indicated by broad arrows. Kinds of responses and orders of succession are often unpredictable. Solid lines with arrows indi- 


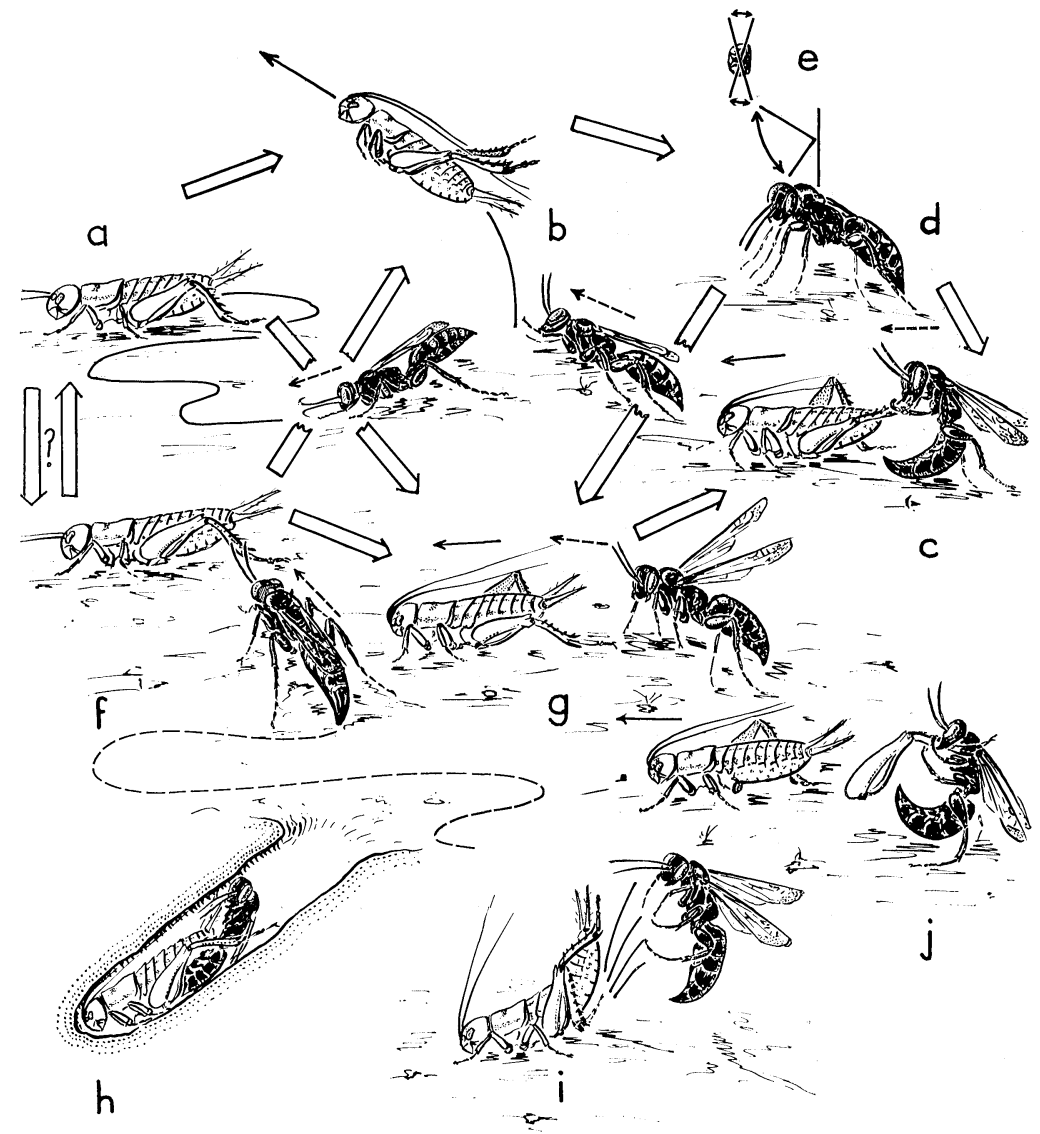

Wasp-prey interactions and responses typical of full hunting phase. Fig. a - Detection of prey by scent; scent-tracking. Fig. b-Attack and escape by jumping away. Fig. c-Capture of the struggling cricket; the wasp often grasps a hind leg with mandibles, legs or both. Fig. d-Typical behavior and posture ("head up") of wasp in situations of disrupted pursuit; arrows indicate side movements to right and left. Fig. e-Detail of side movements of head, seen from above. Fig. $f-D e t e c t i o n$ by sight. Fig. $g$ - Pouncing on cricket (attack), and escape of latter by running away. Fig. $\mathrm{h}-$ Cricket entering a burrow, followed by wasp. Fig. iKicking with hind legs (here the wasp is knocked away). Fig. $\mathrm{j}$-Autotomy of hind leg grasped with mandibles. 
cate movements and displacements of prey, whereas dashed lines with arrows indicate movements and displacements of wasp.

Basic sequence involves detection - by scent (a) or by sight ( $f$ ) or both, - attack of prey and escape of it - by jumping (b) or running (g). It generally ends with capture of prey (c) and is followed by stinging which is not represented here (see Steiner, 1962). Attempt at capture might also trigger less typical responses such as those represented in figures $\mathrm{h}, \mathrm{i}, \mathrm{j}$.

Detection by scent, scent tracking is represented on Plate 22, figure a. The wasp walks slowly, head down with the antennae tapping the soil. Information picked up may be chemical or chemotactile. The wasp, like a hunting dog, follows with great precision the scent trails left by crickets and investigates droppings.

Detection by sight is represented on Plate 22, figure f. The wasp generally walks quickly in an apparent haphazard and irregular way, frequently changes direction, or flies short distances. The wasp does not walk "head down" nor are the antennae tapping the soil. Encounter of crickets is mostly unpredictable, except if the wasp has been guided toward favorable areas by memory of previous hunting trips. Movements and displacements of encountered crickets facilitate detection by sight (see Pl. 22, g).

Detection of prey seems to have important activating effects on the subsequent hunting behavior of the wasp. However, the relative importance, role and possible order of succession of the two methods of detection in the behavior of the wasp are unknown. According to Tinbergen (1935) hunting in another sphecid, the bee wolf (Philanthus triangulum Fabr.), involves a unidirectional succession of sight-scent detection. The two methods of detection are compared in Table 2.

In full hunting phase, detection of the cricket is almost invariably followed by attack (pouncing) and pursuit of the escaping cricket. The behavior of the escaping cricket is variable and unpredictable. Running away (see Pl. 22, g) is frequent, but the cricket might jump away (see Pl. 22, b), stop suddenly under or behind a nearby obstacle, enter a burrow, or change direction.

Therefore, disruption of pursuit is frequent. Typically the wasp instantly stops running and stands upright in a characteristic head up posture with the fore legs stretched to the maximum (see Plate 22, d). The antennae, often vibrating, are held in a special manner. Left and right side movements of the body and often of the head are also performed in quick succession (see arrows on figs. $d$ and e, Pl. 22). Fast visual scanning and exploration of the surroundings 
Table 2. Comparison of characteristics of prey-detection by scent and by sight.

\begin{tabular}{|c|c|c|}
\hline Characteristics compared & $\begin{array}{c}\text { Detection by } \\
\text { scent (Pl. 22, a) }\end{array}$ & $\begin{array}{l}\text { Detection by sight } \\
(\mathrm{Pl} .22, \mathrm{f})\end{array}$ \\
\hline Selectivity of detection & excellent & poor to very poor \\
\hline $\begin{array}{l}\text { Possibility of subse- } \\
\text { quent misidentification, } \\
\text { misdirection of attack }\end{array}$ & exceptional & not infrequent \\
\hline $\begin{array}{l}\text { Delay between detection } \\
\text { and attack }\end{array}$ & $\begin{array}{l}\text { often impor- } \\
\text { tant (trail } \\
\text { following) }\end{array}$ & $\begin{array}{l}\text { short to extremely } \\
\text { short }\end{array}$ \\
\hline $\begin{array}{l}\text { High densities of } \\
\text { crickets, scent trails }\end{array}$ & $\begin{array}{l}\text { apparently } \\
\text { important } \\
\text { "confusing } \\
\text { effect" }\end{array}$ & $\begin{array}{l}\text { no or limited } \\
\text { confusing effect } \\
\text { except in case of } \\
\text { simultaneous escape } \\
\text { of numerous crickets }\end{array}$ \\
\hline $\begin{array}{l}\text { Very low densities of } \\
\text { crickets and important } \\
\text { areas to be explored }\end{array}$ & $\begin{array}{l}\text { good direc- } \\
\text { tiveness, } \\
\text { slow explora- } \\
\text { tion }\end{array}$ & $\begin{array}{l}\text { very poor directive- } \\
\text { ness (random dis- } \\
\text { placements?) } \\
\text { very fast explora- } \\
\text { tion. }\end{array}$ \\
\hline $\begin{array}{l}\text { Detection of motionless } \\
\text { crickets }\end{array}$ & good & $\begin{array}{l}\text { poor, except } \\
\text { apparently at very } \\
\text { sort distances }\end{array}$ \\
\hline $\begin{array}{l}\text { Detection of fast moving } \\
\text { crickets }\end{array}$ & $\begin{array}{l}\text { difficult, } \\
\text { inefficient }\end{array}$ & $\begin{array}{l}\text { easy } \\
\text { highly efficient }\end{array}$ \\
\hline
\end{tabular}

appear to be involved. Short, jerky displacements in zig zag in place or addition of preceding behavior can also be observed. The readiness of attack of any moving object is at its highest level at this point and the selectivity of this response is at its lowest point. This probably results from the combined action of poor visual selective abilities and important lowering of threshold. Although attacks of various inappropriate objects have been obtained experimentally in these conditions, no stinging of any insects other than crickets has been recorded, even if other Ensifera or Caelifera are used (Steiner, I962). This negative result illustrates the contrast between the poor selectivity of some initial stages of attack and the extreme selectivity of the final stages of prey-stinging (details in Steiner, I962). On the other hand, attack of inappropriate objects, such as other Liris, instead of prey, may lead to interesting situational variations in behavior patterns of the wasp. Some of them involve, for instance, a mixture of elements characteristic of both wasp-prey and wasp-wasp interactions (Steiner, 1967). 
Final capture of cricket (represented on Plate 22, fig. c) is tumultuous and quite difficult. Not infrequently the wasp fails to secure its prey. She uses her mandibles and legs in grasping parts of the struggling cricket, very often one of the hind legs. Success depends mainly on the ability of the wasp to sting the cricket as soon and as quickly as possible. This generally prevents the cricket from escaping by increased struggling or from performing one of the following responses (see Plate 22).

Fig. h. Entering a burrow. This does not necessarily prevent the cricket from being stung, but it increases the chance of escaping, especially if the burrow is very narrow. The first sting, which results in paralysis of the jumping legs, is often crucial because after that, the wasp is generally able to drag the cricket out of the burrow and to give the additional three stings (Steiner, 1962).

Fig. i. Kicking with jumping (hind) legs. Generally this is not very efficient in full hunting phase, unless the cricket disappears quickly, which is generally not the case. As a mater of fact, if the wasp has not been kicked away too far, she quickly comes back to the cricket.

Fig. j. Autotomy of the hind leg grasped by the wasp. This provides a good opportunity of escape, the wasp frequently being kept busy with the autotomized leg in her mandibles! Observed frequently in captivity (Steiner, 1962), this behavior also seems widespread ir field conditions. Several authors have reported frequent occurrence in nests of Liris, of paralyzed crickets deprived of one or two hind legs (Berland, 1925; Ferton, 1905). Accumulation of hind legs in some nests have even been described by Piel (1933).

Finally, probability of capture might also be reduced if the attacked crickets are very large or very small and if the wasp is not in optimal physiological condition; this seems to be the case very early or very late in the reproductive season, for instance.

\section{EXCEPTIONAL BEHAVIORAL RESPONSES OF PREY IN SPECIAL HUNTING} conditions (see Plate 23).

Basically, these exceptional responses (about a dozen in several hundred observed attacks) involve sudden and total immobilization ("freezing") of the cricket in special hunting situations. The final postures are represented in Plate 23, figures d, i.

Detection, attack and initial phase of pursuit were as usual (see $\mathrm{f}, \mathrm{g}$ ) but the cricket suddenly stopped beneath an obstacle, e.g., a stone $($ see $h)$. As the wasp tried to catch it the prey again ran away, being followed by the wasp. The cricket then stopped suddenly, 


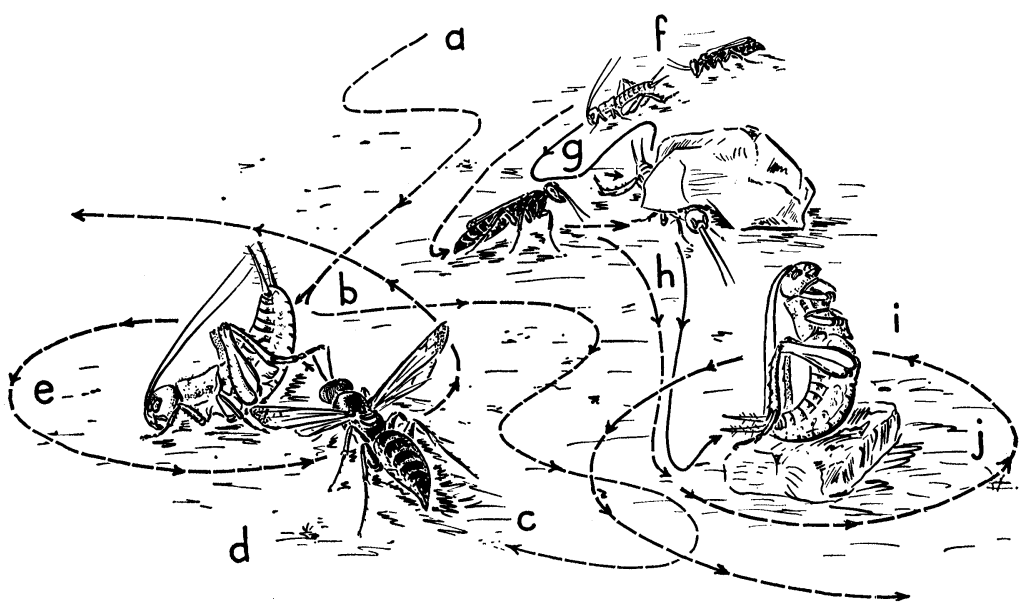

Wasp-prey exceptional responses. Figs. a, b-First attack, abortive and weak. Fig. c-Renewed and vigorous attack, the wasp pouncing suddenly on the cricket. Fig. d- "Freezing" of cricket (in kicking posture?). Fig. e -Wasp circles the "frozen" cricket several times and walks away. Fig. $f$ - First attack and pursuit. Fig. $\mathrm{g}$-Cricket stopping under a stone, where attacked again, with increased vigor. Fig. $\mathrm{h}$ - Cricket escapes again, followed by wasp. Fig. i - "Freezing" of cricket on top of a small obstacle (in jumping posture?). Fig. j-See e. 
but on top of a small obstacle (pebble, clump of earth, etc.) and in a special "freezing posture" (see Plate 23, $\mathrm{d}$ and i and Steiner, 1962). In most instances the wasp did not pounce on it subsequently. In only one out of the few instances it did so, actual stinging followed. In one other instance the wasp grasped the cricket after having pounced on it, but released it immediately, still in the same state, after an abortive attempt at stinging. In the majority of instances observed, the wasp circled the "frozen cricket" several times and walked away (see e, $\mathbf{j}$ ). "Freezing" in the posture represented in figure $d$ was sometimes observed after the wasp pounced back on a cricket investigated shortly before (see b).

Discussion is centered around the three following questions:

I. What is relevant to the response of the cricket in the hunting context?

2. Does the response of the cricket influence the hunting behavior of the wasp, and if so how and why?

3. What is the meaning of the different postures and responses of the cricket, and what are the mechanisms involved?

I. What is relevant to the response of the cricket in the hunting context? In general, freezing responses were associated with the following exceptional conditions:

a. Wasp-cricket interactions involved repeated or disrupted attacks of increasing vigor at short intervals. It is not known whether repetition and disruption of attacks are the important factors or the short interval, delay, separating them or their rapid increase in vigor. Even the perseverance of the wasp might be involved. No freezing has been observed early in the hunting phase, when attacks of the wasps are weak and abortive.

b. Proximity of an obstacle in the environment might induce the escaping cricket to stop. If the obstacle is too small for sheltering, jumping away from the top of it might be attempted but ultimately inhibited (see Plate 23, the posture shown on figure $i$ and question 3, below).

2. Does the response of the cricket influence the behavior of the wasp and if so, how and why? "Frozen" crickets were investigated by the wasp, attacked and stung in only a very low proportion of the observed instances (one would rather expect the contrary in situations of disrupted attacks).

If it is not an artifact of small sampling, this apparent effect could be related to absence of movement of the cricket or to other properties of the freezing posture or both. Attack and stinging evidently depend strongly, but not exclusively, on movement. In general, 
the wasp gives the whole set of four stings only if reactions of the attacked cricket are sufficiently intense. However, investigation generally takes place whenever a nesting wasp finds a cricket, be it motionless or even paralyzed, except that wasps engaged in nest digging or nest closure generally ignore crickets. Stinging follows mainly if the investigated cricket reacts vigorously; if not, malaxation is more probable (Steiner, I962).

Therefore, rarity of investigation of "frozen" crickets (perhaps even of attack and stinging) might be related in part to special properties of the fireezing posture. Absence of movement might or might not have additional effects. Regardless, the aspect of the "frozen" cricket and the outcome of its behavior are quite unusual (see Logan, I96I and question 3 below).

3. What is the meaning of the different responses of the cricket, and what are the mechanisms involved? Most of the responses described in Plates $2 \mathrm{I}$ and 22 might be interpreted in terms of general defense or alarm reactions and not necessarily in terms of special predator-prey or parasite-host reactions. Even autotomy of hind leg ( see Plate 22, j) can be obtained experimentally with crickets using stimuli as different and unspecific as heat, pressure, chemicals, stings, etc. (Brousse-Gaury, I958, etc.). However, similar responses have also been observed in predator-prey interactions, e.g in some species of crabs.

The meaning of the freezing responses of the cricket in this respect and the mechanisms involved are far from clear. Predator-prey interactions are highly complex and involve many problems beyond the scope of this paper. Different possibilities are only briefly mentioned below. More information is available in the literature cited.

Sudden immobilization, "freezing", has been described in many insects and other animals in various conditions and under a variety of terms such as "reflex-immobilization" (Rabaud, I9I9, etc.), "voluntary immobilization" (Piéron, I959), cataleptic, paralytic or hypnotic states, immobility response, "death feigning", total inhibition of movement, thanatosis, etc. (see also, for instance, Bleich, 1927; Hoffmann, I92 I, I926; Holmes, I906; Löhner, I914 ; Saxena, I958; Steiwiger, 1933). Cessation or recovery of movement or both can be associated with general disturbances, with precise stimulation of certain parts of the body and with visual stimulation (see Gautier, I965, I967; Rabaud, I919; Szymanski, I917; Weyrauch, r929). The "frozen" animal might also recover spontaneously. Emphasis is often placed on strong inhibitory influences. Muscle hypertonus is frequently reported in insects, for instance (Rabaud, 1919). Loss 
of excitability is said to be characteristic of "reflex-immobilization" (Rabaud) but not of "voluntary immobilization" (Piéron).

If one pushes a cricket "frozen" in the posture represented on figures $\mathrm{d}$ or $\mathrm{i}$, it falls over. Careful manipulation does not disrupt the "cataleptic state". Recovery is generally spontaneous.

Differences in the postures represented on figures $d$ and $i$ might be related to differences in the kinds of activity the cricket was performing when freezing ("petrifaction") occurred. Figure i (Plate 23) might represent a cricket "frozen in a jumping posture" and figure $\mathrm{d}$ a cricket "frozen in a kicking (or in a tail erect) posture" (compare figures $\mathrm{i}$ and $\mathrm{d}$ with figures e and d, Plate 2I). Some support for this can also be found in discussion of question $I$, above.

Some predator-prey reactions or characteristics are also interpreted sometimes in terms of avoidance of release and "negative releasers" (see Tinbergen, 1966, etc.). "Frozen" crickets might be "negative releasers" with respect to stinging, attack and even investigation.

Numerous examples of "intimidatory postures", and reactions, "bluff behavior", can also be found in the literature (see for instance Hinsche, 1939, 1942; Prop, 1960).

Many examples of "mimetic immobility responses" and mimicry of unpalatable or dangerous species have been reported too (see for instance: Carrick, I936; Ford, I964; Klopfer, I962; Sheppard, 1959). Whether or not "frozen crickets" belong to one of these categories is not known, but seems improbable.

The same can be said from "protean displays", polymorphism. Multiple and frequent changes in appearance, behavior and posture might produce a "confusing effect" on the predator (see for instance Chance, et al., 1959).

In conclusion, a considerable amount of experimentation is needed before the meaning and mechanism of all Liris-cricket interactions and responses can be clearly understood.

\section{Acknowledgements}

I am especially indebted to Professor P.-P. Grassé who initiated this project, and also to the following persons: Dr. L. Berland, Museum d'Histoire Naturelle, Paris; Dr. P. Maillet, Station Biologique, Les Eyzies, France; Dr. E. P. Deleurance, Université de Marseille (C.N.R.S.), France, for basic information concerning general technique of raising Hymenoptera in captivity, and behavior of Hymenoptera; Dcctors H. E. Evans, Mus. Comp. Zool., Harvard University, Cambridge, U.S.A.; H. F. Clifford, University of Alberta, (Zoology), Edmonton, Alberta, Canada, and G. E. Ball, 
University of Alberta, (Entomology), Edmonton, Alberta, Canada for reading, editing the manuscript and for offering helpful suggestions.

BerLAND, L.

\section{Literature Cited}

1925. Hyménoptères Vespiformes. I. Sphegidae, Pompilidae, Scolidae, Sapygidae, Mutillidae, Lechevalier, Paris, 364 pp.

1929. Notes sur les Hyménoptères de France. XIV. Le terrier de Bleich, O. E. Notogonia pompiliformis Panz. Bull. Soc. Entom. Fr. 4: 66-67.

1927. Thanatose und Hypnose bei Coleopteren. Experimentelle Untersuchungen. Z. Morph. u. Okol. Tiere. 10: 1-61.

Brousse-Gaury, R.

1958. Contribution à l'étude de l'autotomie chez Acheta domestica Carrick, R. L. Bull. Biol. France Belg. 92: 55.

1936. Experiments to test the efficiency of protective adaptations in insects. Tr. Roy. Ent. Soc., London. 85: 131-140.

Chance, M. R. A. And W. M. S. Russell

1959. Protean displays: a form of allesthetic behaviour. Proc. Zool. Soc., London. 132: 65-70.

Ferton, Ch.

1901b. Notes détachées sur l'instinct des Hyménoptères mellifères et ravisseurs, avec la description de quelques espèces. lère série. Ann. Soc. Ent. Fr. 70: 83-148.

1905. Notes détachées sur l'instinct des Hyménoptères mellifères et ravisseurs, avec la description de quelques espèces. 3e série. Ann Soc. Ent. Fr. 74: 56-103.

1911. Notes détachées sur l'instinct des Hyménoptères mellifères et ravisseurs, avec la description de quelques espèces. $7 \mathrm{e}$ série. Ann. Soc. Ent. Fr. 80: 351-412.

1914. Notes détachées sur l'instinct des Hyménoptères mellifères et ravisseurs avec la description de quelques espèces. $8 \mathrm{e}$ série. Ann. Soc. Ent. Fr. 83: 81-118.

FORD, E. B.

1964. Ecological Genetics, Methuen, London.

GaUtier, J. Y.

1965. Problèmes de la mise en activité et de l'arrêt de l'activité chez les Inscctes. Union Internat. Sci. Biol. Section Psychol. Exp. Comport. Anim., Marseille, Fr. 4-5 Oct. 1965.

1967. Immobilisation réflexe liée à des excitations tactiles du pronotum chez les larves de Blabera craniifer (Burm.) normales ou recevant des implantations de corps allates. C. R. Acad. Sc. Paris. 264: 1319-1322.

GRANDI, G.

1954. Contributi alla conoscenza degli Imenotteri aculeati. XXVI. Boll. Ist. Ent. Univ. Bologna. 20: 81-255.

Hinde, R. A.

1966. Animal behaviour, McGraw Hill, (pp. 245-290). 
Hinsche, G.

1939. Über die Entwicklung von Haltungs-und Bewegunsreaktionen. Roux' Arch. 139: 724-931.

1942. Aktivierung latenter Kampfreflexe bei niederen Wirbeltieren (Anuren). Forsch. u. Fortschr. 18: 158-159.

HoFfMAN, R. W.

1921. Üntersuchungen ueber experimentelle Hypnose bei Insekten und ihre Beziehungen zum Beruhruengsreiz. I. Nachr. Kgl. Ges. Wiss. Göttingen 171-187.

1926. Refleximmobilization (review). Handb. Norm. Path. Physiol. $17: 690-714$.

Holmes, J. S.

1906. Death feigning in Ranatra. J. Comp. Neurol. Psychol. 16:200-216. KLOPFER, P. H.

1962. Behavioral aspects of ecology, Prentice-Hall, $166 \mathrm{pp}$.

KoHL, F. F.

1884. Die Gattungen und Arten der Larriden (Sphecid.) Autorum. Verh. K.K. Zool. Bot. Gesellsch. Wien. 171-454.

Logan, F. A.

1961. Specificity of discrimination learning to the original context. Science. 133 : 1355-1356.

LÖHNER, L.

1914. Untersuchungen ueber den sogenannten Totstellreflex der ArthPí́ron, H. ropoden. Z. Allg. Physiol. 16: 373-418.

PROP, N.

1959. De l'Actinie à l'Homme, P.U.F., Paris.

1960. Protection against birds and parasites of some species of Tenthredinid larvae. Arch. Neerl. Zool. 13: 380-447.

RABAUd, E.

1919. Bull. biol. Fr. Belg. 53 : 1-149.

SAXENA, S. C.

1958. An experimental study on thanatosis in Armadillidium vulgare (Latreille). J. Zool. Soc. India. 9: 192-199.

SHEPPARD, P. M.

1959. The evolution of mimicry: a problem in ecology and genetics. Cold Spring Harbor Symposium on Quantitative Biology. 24: 131-140.

Steiner, A. L.

1957a. Contribution a l'étude biologique des Sphégides (Hyménoptères). IIa. Comportement "fouisseur" de Liris nigra V.d.L. (Notogonia pompiliformis Panz.) C.R. Acad. Sci. Fr. 244: 1259-1261.

1957b. Contribution . . II Ib. Comportement "fouisseur" de Liris nigra V.d.L. (=N.p. Panz.). C.R. Acad. Sci. Fr. 244: 1818-1820.

1957c. Contribution . . . III. Les activités en relation avec la prole, chez Liris nigra V.d.L. (=N.p. Panz.). C.R. Acad. Sci. Fr. 244: 2105-2107.

1958a. Contribution .. . V. L'influence des piqures de Liris nigra V.d.L. (=N.p. Panz.) sur sa prole. C.R. Acad. Sci. Fr. 247: $150-152$ 
1958b. Contribution . . . VI. La valeur réactogène différentielle des diverses régions corporelles du Grillon, proie de Liris nigra V.d.L. (=N.p. Panz.). C.R. Acad. Sci. Fr. 247: 970-972.

1962. Etude du comportement prédateur d'un Hyménoptère Sphégien: Liris nigra V.d.L. (=N.p. Panz.). Ann. Sci. Nat. (Zool.) Fr. $12 \mathrm{e}$ Ser. (IV) : $126 \mathrm{pp}$.

1963a. Interprétation neuro- et psychophysiologique de l'état des victimes de certaines Guêpes paralysantes (Liris nigra V.d.L. $=$ N.p. Panz.) (Contribution à l'étude des facteurs motivationnels et activateurs chez l'Insecte). C.R. Acad. Sci. Fr. 257: 3480-3482.

1963b. Etude des influences possibles de la vie larvaire, sur le comportement prédateur de l'adulte, chez une Guêpe Solitaire: Liris nigra V.d.L. (=N.p. Panz.) (L’inné et l'acquis dans le comportement de l'Insecte). C.R. Acad. Sci. Fr. 257: 3676-3678.

1965. Mise au point d'une technique d'élevage d'Hyménoptères fouisseurs en laboratoire (Note préliminaire). Bull. Soc. Ent. Fr. $70: 12-18$.

1967. Some situational variations in basic patterns of behavior in the Solitary Wasp Liris nigra V.d.L. (Hym. Larrinae). Xth Internat. STEIWIGER, F. Ethol. Confer. Stockholm, Sweden, Sept. 1967.

1933. Die Erscheinungen der Katalepsie bei Stabheuschrecken und Wasserluefen. Z. Morph. u. Okol. Tiere. 26: 591-708.

SZYMANSKI, J. S.

1917. Die sogenannte tierische Hypnose bei einer Insektenart. Arch. Ges. Physiol. 166: 528-530.

Tinbergen, N.

1935. Über die Orientierung des Bienenwolfes (Philanthus triangulum Fabr.) II. Die Bienenjagd. $Z$. vergl. Physiol. 21: 699-716.

1952. Derived activities: their causation, biological significance, origin and emancipation during evolution. Quart. Rev. Biol. 27: 1-32.

1966. Social behaviour in animals, Methuen, London. WEYRAUCh, W. K.

1929. Die Hypnose bei Forficula. Z. Morph. Okol. Tiere. 15: 109-155. 

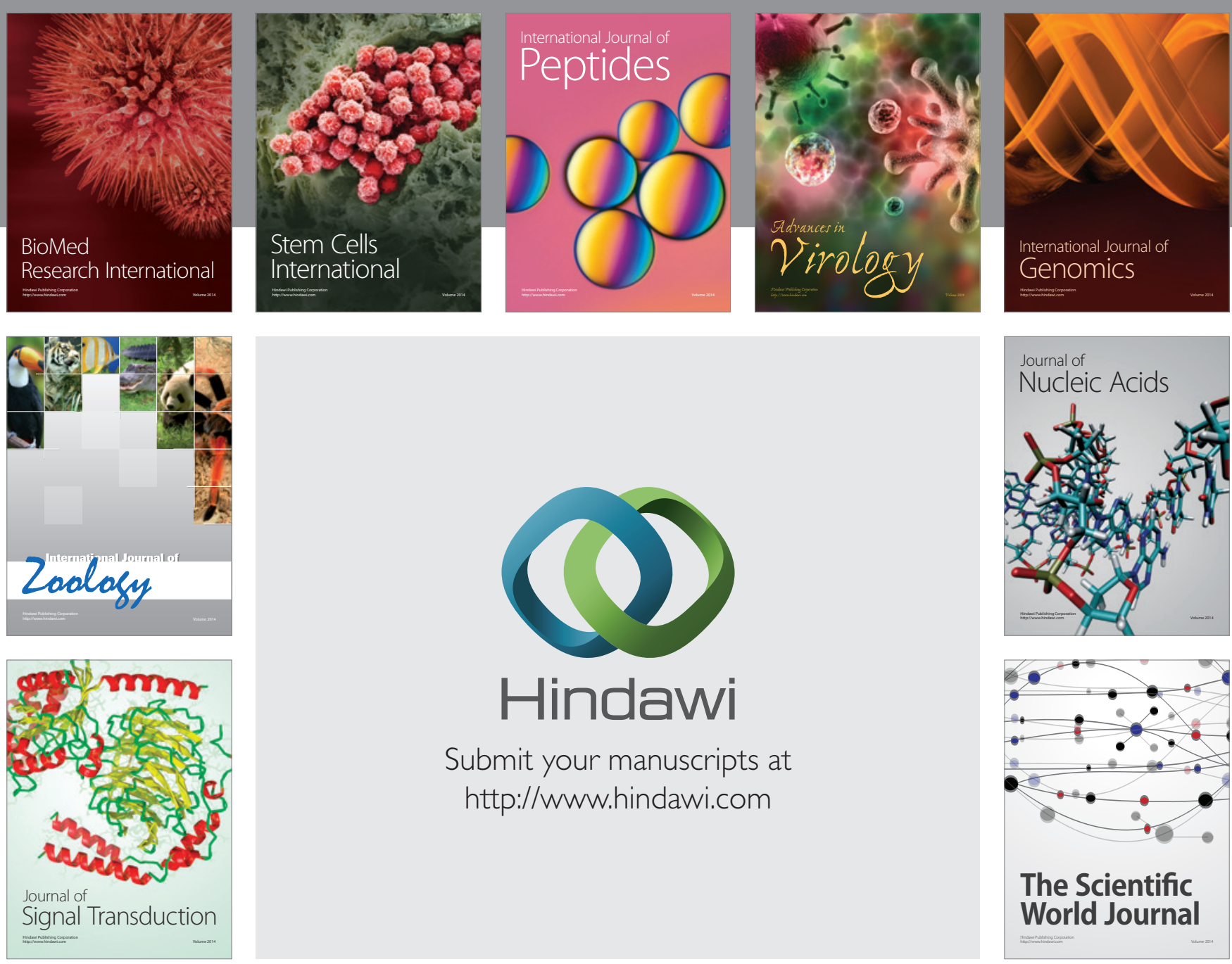

Submit your manuscripts at

http://www.hindawi.com
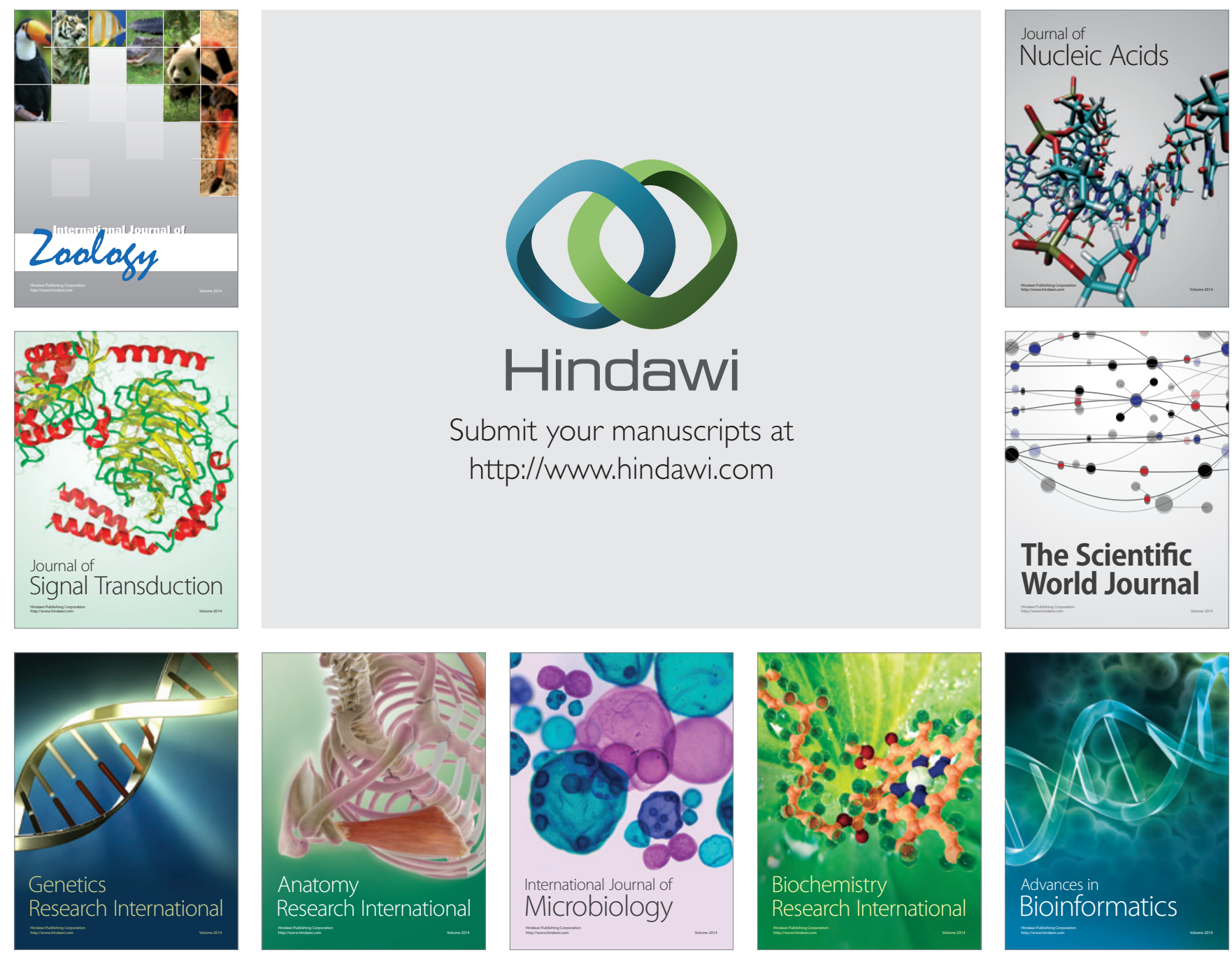

The Scientific World Journal
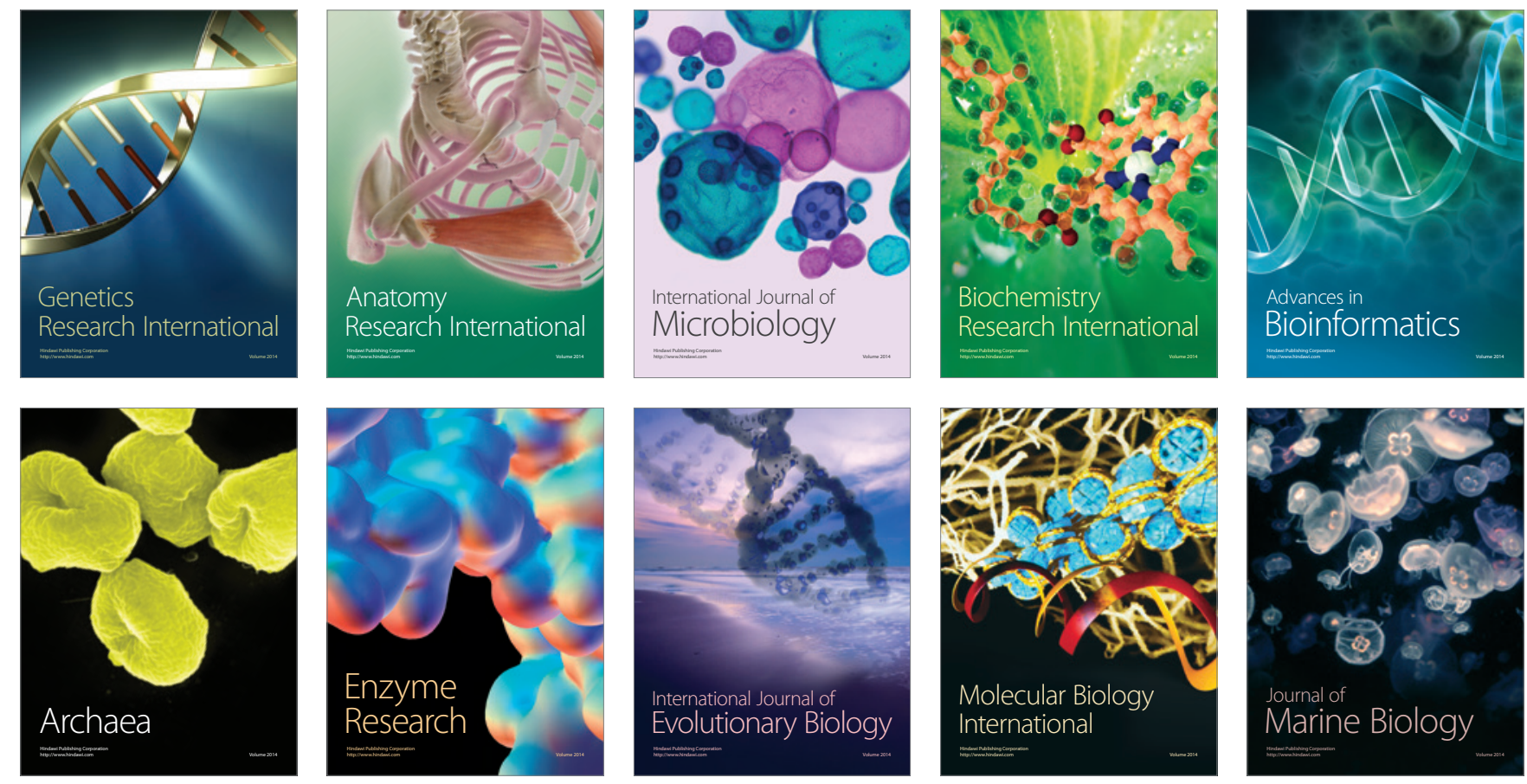